Journal of African Real Estate Research

Volume 3, Issue 1

\title{
Factors Influencing the Deployment of ICT in Nigerian Real Estate Practice
}

\author{
Abiodun Kolawole Oyetunji ${ }^{1}$, Babajide $\mathrm{Ojo}^{2}$, and Busayo Oyetunji-Olakunmi ${ }^{3}$ \\ ${ }^{1}$ Department of Estate Management, Faculty of Environmental Sciences, University of Benin \\ 2,3 Department of Estate Management, School of Environmental Technology, Federal University of \\ Technology, Akure.
}

To cite this article: Oyetunji, A.K., Ojo, B., \& Oyetunji-Olakunmi, B. (2018). Factors Influencing the Deployment of ICT in Nigerian Real Estate Practice. Journal of African Real Estate Research, 3(1), pp.1-20. DOI: $10.15641 /$ jarer. v1i1.561

\begin{abstract}
Real estate is an intensive business that largely depends on information. Information technology has become a major form of communication in the real estate industry, a tool for marketing and information dispersion. As a result, diverse factors influence the use of information and communication technology (ICT). This study is aimed at investigating the factors influencing the use of ICTs in Nigerian real estate practices. Lagos state, the area of study, was delineated according to a central business district locational pattern to ascertain where the firms of real estate were grouped. Out of the 172 questionnaires that were conveniently administered to real estate firms within the study location, only 143 (83.14\%) were retrieved and considered valid for the analysis. The collected data was then analysed using a factor analytical test. Findings revealed that technological infrastructure, service delivery efficiency enhancement, and productivity branding influenced the deployment of ICTs in Lagos' real estate industry. It was recommended that practitioners and real estate firms need to adopt emerging concepts and technological advancement in their quest for survival both locally and internationally. This will enhance their competitiveness and ensure that better value is provided.
\end{abstract}

Keywords: Real Estate Practice; ICT; Factors Influencing Globalization; Technology

\footnotetext{
1+2347031606666, abiodun.oyetunji@uniben.edu

2+2348035011142, bojo@futa.edu.ng

3+2348038078236, bussykunmi@gmail.com
} 


\section{Introduction}

During the late 1990s major structural changes brought about by globalisation, and Information and Communications Technologies (ICTs) shifted the norms of economics. Interconnectivity became the order of the day as technology and its capabilities were discovered. According to McAusland (2010), globalisation is a complex occurrence that has led to challenges but also opportunities for individuals and organisations in various fields. Economic globalisation has led to the emergence of a new world order characterised by geographically decentralised production, internationalisation and cross-boundary activities (McAusland, 2010). Within this international context, technology continues to improve and subsequently enhance the efficiency, performance and overall productivity of firms who employ it for their service delivery (Hamdi, 2013).

Before the globalisation surge, prominent technologies included radio, TV and print media. More recent technology development encompasses software information systems, internet connectivity, mobile phones and computers (Apulu \& Latham, 2011). ICTs represent the most important industry in the world today (Swanepool \& Tuccilino, 2003). Access to, and the usage of, technological facilities occurs with so much flexibility that it redefines man's interaction with people, business, governments and the environment (Crowston, Sawyer \& Wigand, 2001; Agarwal \& Karahanna, 2002; Zumpano, Johnson \& Anderson, 2002). Modern ICT applications have been useful for automating processes such as information acquisition, resource sharing, data analysis, colocation using spatial data, decision support and social networking. ICT has become vital in handling and transferring data between individuals, businesses and machines themselves (Wigand et al, 2001).

The emergence of ICTs has influenced the business activities of real estate practitioners (Swanepool \& Tuccilino, 2003; Kakulu, 2008; Babawale, 2012). Globally, real estate practices and purposes remain the same, but the mode of practice is subject to its geographic and cultural context (Dixon \& Thompson, 2005; Reijo et al., 2007). The introduction of ICTs, particularly in other sectors of the economy, has led to changes in the conventional working process of real estate in Nigeria (Kakulu, 2008). The application of ICTs to real estate practice has provided a better corporate image, while simultaneously influencing business profitability (Sawyer et al., 2003). For example, in real estate agency practice, Cruzen (2006) stated that globally, 36 million visitors entered real estate websites in search for properties on the internet in 2006, compared with the 16 million visitors in 2001.

Information is essential to the real estate business. Information technology is a major form of communication - a tool for marketing and information dispersion. As a marketing tool, information technology gives extensive coverage to reach potential clients. Furthermore, information gathering is faster and more accurate. Additionally, it is probably the cheapest way to sell 
products (Olukolajo, Ojo \& Akinwamide, 2015). Estate agents connect buyers to sellers through control and dissemination of information. Clients value the role of the agents because of the information skills they offer in both listings and sales. In Nigeria, the adoption of information technology for real estate transactions began with a property website where property information was published. However, a number of challenges (such as the failure of the site to effectively meet customers' needs, unfulfilled promises on services, and nonfunctional or non-existent links) have discredited this medium (Chukwuemeka, 2012). The versatility of ICTs has led to its adoption in real estate services in Nigeria, but challenges have hindered the growth of its use.

According to Gwin (2004), potential buyers and/or sellers can easily and effectively find and compare properties, location and prices. Furthermore, both parties are given access to a multitude of real estate "e-information" with the click of a mouse even before contacting an agent. Globally, the studies of Wigand et al. (2001); Kirkwood (2003); Sawyer et al. (2005); Reijo et al. (2005, 2007) in the United States, and Peansupap and Walker (2005) in Australia have shown that real estate practice has been computerized with indepth use of ICTs. Other studies by Sing (2005) in Singapore; Yang, Ahuja and Shankar (2007) in India; Alam and Moh'd-Kamal (2007) and Alam et al. (2011) in Malaysia, established that different factors motivate the use of ICTs in real estate practice in developing Asian countries.

This paper aims, therefore, to examine the extent and determinants of ICT adoption in a sample of real estate firms in Lagos, Nigeria. The study focusses particularly on the usage of ICTs to promote services in real estate. While some firms are at the forefront of ICT applicability for effective service delivery, others are yet to reach such a level. To achieve the aim of the research, the following questions are pursued:

i. What are the critical factors that impact the effective deployment of ICTs in Nigeria's real estate practice in the study area?

ii. To what extent have ICTs been adopted for effective delivery of real estate services in the study area?

The study aims to extend the frontiers of knowledge on the subject beyond the European and Asian experiences. It looks at real estate related ICT from the context of a developing economy in Africa. By identifying the factors influencing the deployment of ICTs within real estate firms, stakeholders involved in the delivery of real estate services will be able to fulfil the mission of promoting the use of ICTs and enhance their innovative and competitive capabilities through the utilisation of the technologies.

The data for the study is based on a survey of the knowledge of real estate practice and the rationale of thriving businesses in comparison to their less successful counterparts. The survey was conducted on 172 firms during a six- 
month period (July-December 2017). The characteristics of the firm, factors that motivate the deployment of ICTs, and the aspects of real estate for which ICTs are used are at the core of this investigation. The need for this study to be conducted in Africa and particularly Nigeria, is a result of the fact that ICT deployment in the real estate sector is comparatively lower to other national sectors in the economy. Also, the Nigerian Institution of Estate Surveyors and Valuers (NIESV) does not permit practising firm to advertise in an overtly competitive manner.

This paper is structured to include an introduction to ICT and its relevance in contemporary real estate practice. This is followed by an assessment of ICT in real estate practices of developed and developing economies. The paper then highlights the research methodology of the study, the results and a discussion of findings from the research. It concludes with final remarks and recommendations.

\section{Assessment of the Adoption of ICTs in Real Estate Practice}

According to Kasim and Ang (2010), ICT is a technology dedicated to information storage, processing and communications. It involves a combination of hardware, software and networks that transform raw data into useful information for efficient retrieval (Gaith, Khalim \& Ismail, 2009). The rate of change brought about by the introduction of ICT has led to the reorganisation of work patterns, skills and job retraining in many professions (Ogunsola \& Aboyade, 2005). Real estate practices all over the world are information sensitive and intensive. The value of information skills available to Estate Surveyors and Valuers (ESV) determines how they connect landlords, tenants, sellers and buyers. Real estate professionals have embraced ICTs to maintain a competitive edge over other professionals and the market (Reijo et al., 2005; 2007).

The real estate industry is based on a competitive consumer culture in which professionals vie for business and ultimately, customers' loyalty (Jones \& Benjamin, 2013). The presence of an agent makes real estate unique from retail and other industries where goods and services trade hands. The rise of various ICT applications over the years has led to new challenges for real estate agents and related professionals. Markus et al. (2008) notes that the increased prevalence of ICTs in various industries can become disruptive, causing individuals and organisations to either adapt or become obsolete. One of the most consistent patterns in business is the failure of leading companies to stay at the top of their industries when technologies or markets change.

Information and Communication Technology is a space where increased investment is necessary to remain competitive in the market. Investment within the ICT industry allows one to increase efficiency, reduce timescales and cost, and raise the entry level for a contracting business (Real Estate Insight, 2010). 
Notwithstanding the apparent advantages of ICTs, it is commonplace today that the real estate industry invests little in ICTs. In comparison to other sectors of the economy, financial services and manufacturing industries, the real estate world has been considerably slower at exploiting the potential of ICT (Egbu \& Botterill, 2002).

According to Crowston, Sawyer and Wigand (2001), the adoption of ICTs is influenced by individuals who change the conduct of their work in response to the availability of computing and communication technologies. The development and accessibility of ICTs has influenced all spheres of real estate practices, and its usage has brought about benefits to the profession (Dixon \& Thompson, 2005). In real estate practice, the areas of application of ICTs include valuation property appraisal, construction design and management, property maintenance, estate agency and marketing, portfolio management, facility management, and administrative record keeping (Kakulu, 2003; Kirkwood, 2003). Cutting across these areas is the innovation of geographic information systems (GIS), which have been established as a distinct field of academic study for real estate practice. Kirkwood (2003) and Chang (2004) state that even though ESVs have embraced the use and integration of ICTs, many continue to work within the traditional paradigm of the profession.

Kummerow and Lun (2005) highlight that firms tend to achieve wider coverage due to their investment in ICT. Cheong (2006) also concluded that there is need for real estate professionals to evolve in cognitive change towards contemporary professional practices. Professionals must work with the advancements in information technology, specialisation, and master the new knowledge and techniques. The uniqueness of the real estate industry poses challenges to the implementation of automation and ICTs (Nielsen et al., 2007). In the face of these challenges however several factors demonstrate that the nature of the real estate industry is changing. Nielsen et al., (2007) asserts that, the use and adoption of ICTs in the construction industry is influenced by factors such as the project's value, technological capability of the parties involved, and previous experience with ICTs. Other factors include client demand, number of parties involved, the need for greater transparency, information overload and the need to reduce paper workload. Furthermore, factors such as partnering and the desire for better collaboration as well as the need for better and faster communication must be noted (Nielsen et al., 2007).

According to Perkinson and Ahmad (2006), the factors could also include an extensive lack of skilled workers, growing average age of staff, the inability to attract and retain talented/educated personnel, and increased industry competition. Other factors pointed out by Perkinson and Ahmad included the need for working in dangerous/inaccessible areas of operation, increased requirements for the quality of the work execution, and an increase in performance and reduction in costs. These factors are required to maintain a competitive advantage. Despite these factors and the inherent benefits of ICTs, 
their utilisation in real estate services is yet to be fully embraced. This is evident in various firms where they continue to carry out their respective activities using traditional methods such as paper filing systems in cabinets and the use of manual typewriters. The under-exploitation of ICT could be attributed to the complex nature of the industry; financial constraints, poor availability of tools/software and improper understanding of the ICT implementation process (Perkinson and Ahmad, 2006).

Several studies have been carried out on ICTs and their associated relevance to real estate practice both in developed and developing economies (Muhanna, 2000; Crowston et al., 2001; Li \& Wang, 2006; Oladapo, 2006; Adeyemo et al., 2015). For instance, Muhanna (2000) carried out a study on e-commerce in the real estate brokerage industry by assessing the perception of 150 real estate firms in Columbus, Ohio. The analysis was done using t-Tests and Analysis of Variants (ANOVA) techniques. The findings suggested that the size of the firm was a key determinant as to whether the firm is on the internet. The study, however, did not consider the respondents' views about the factors that motivate the use and the adoption of ICTs into real estate practice. Rowley (2005) studied the evolution of internet business strategies in the United Kingdom (UK) estate agency. This study focused on the relationship between business internet integration and service delivery. The study found that websites provide information, advice and newslinks to other businesses, search facilities, and provides opportunities for registration on estate agents' sites, which supports personalisation of communication with customers. The study considered internet business strategy to enhance service delivery in the UK and not in Nigeria. Li and Wang (2006) conducted a study on real estate agency in China. The study focused on the application of the internet to real estate agency practice in China. Findings revealed that the internet allowed agencies to broaden their business opportunities and served as a connection between the agencies and a fragmented customer base. The impacts and changes felt by Beijing real estate agents resulting from changes in information technology were highly correlated with parallel changes in the socio-economic system in China.

Oladapo (2006) evaluated the impact of ICTs on professional practices in the Nigerian construction industry. This was done by surveying the current state of ICTs in architectural, engineering and quantity surveying practices in the South-Western construction industry. Findings revealed that while core functions have largely been computerised, data and documentation management is still done manually. Ashaolu (2011) examined the environmental benefits and challenges of ICTs in Lagos. A questionnaire surveyed business office users across different occupations and the results were analysed on a 5-point Likert scale. The results showed that among other benefits ICTs facilitated commuting and work habits among other benefits. The study investigated the use of different ICT media and its propensity to 'telework' by taking advantage of different ICT facilities. 
Esben (2012) assessed the factors hindering ICT usage in the construction industry in Ghana. A survey-based questionnaire was used to elicit data from 51 contractors. The result revealed that there is a reasonable level of awareness among the contractors about the potential benefits of ICTs. However, current ICT usage in most Ghanaian firms was found to be unsophisticated and more advanced applications were lacking. Gitau (2014) carried out a study to examine the impact of information technology and the extent of applications and implementation within real estate firms in Kenya. The study further examined the variations in firms' responses, and how increasing use of ICTs impact on firms' operational activities. Primary data was collected using a questionnaire survey conducted on 153 firms randomly selected from office buildings located in the Central Business District (CBD) of Nairobi and other key submarkets on the fringe of the CBD. Findings revealed that ICTs have a significant, positive impact on the way real estate firms carry out their activities.

Adeyemo et al. (2015) explored the motivating factors influencing the use of ICTs in real estate practice in Minna, Nigeria. Survey data was collected to examine the relationship that existed between internal and external motivating factors. The study categorised the motivating factors into external and internal categories and used a sample of 15 estate firms, which are limiting barriers to the effective use of factor analysis. The result indicated an increased productivity of staff, enhanced quality of customer services, knowledge sharing, information accessibility, improved decision-making, and time-saving as internal motivating factors. The external motivating factors which influence firms, alongside competitors' pressure, also depend on the availability of ICT infrastructure, management, business size and overall cost. The study also revealed that there is a negative correlation between internal and external motivating factors.

Empirical studies on ICT adoption have yielded ambiguous results. While some studies found a positive relationship between firm size and the adoption of ICTs (Arduin, Nascia \& Zanfei, 2010; BenYoussef, Hadhri \& M'Henni, 2010; Gallego et al., 2011), other studies have shown an insignificant or a negative correlation between them (Bayo-Moriones \& Lera-Lopez, 2007; Bocquet \& Brossard, 2007; Bocquet Brossard \& Sabatier, 2007). Furthermore, Hollestein (2004) maintains that the relationship is non-linear by asserting that firm size has a positive impact on the adoption and use of ICTs. Despite these studies, no logical conclusion has been reached as to the inherent factors that have motivated the use of ICTs in the Nigerian real estate sector. The findings of most research on ICT usage and its application have not identified the major factors that can be said to influence the adoption of ICTs in real estate practice in Nigeria and particularly the study area, Lagos. This gap in the literature is therefore the basis for this study. 
The factors utilised for investigation were extracted from the literature review. The need to increase productivity, to make staff responsibilities easier, time saving and management, and to enhance decisio-making were adopted and modified from Sawyer and Crowston (1999). Increasing competition level among practitioners, size of firm, attracting more clients, and changing trends in technology were taken from Oladapo (2006). Factors such as the need to improve the firm's quality of services, to increase the firm's rate of turnover, to create more opportunities, and to portray the firm's image were modified and sourced from Asgarkhani and Young (2010). The need to eliminate distance barriers, ease of information transfer, and affordability of computer software and hardware were selected from Spanos, Prastacos, and Poulymenakou (2002).

\section{Methodology}

The study set out to investigate the factors responsible for the use of ICTs in real estate practice in the Nigerian economy. The practice of real estate in Nigeria thrives in Lagos, Port-Harcourt and Abuja. Since the entire Nigerian property market cannot be explored due to limiting factors, the scope of this study is limited to the Lagos metropole. This is because the vast majority of Nigeria's real estate profession pools here. Lagos, being the commercial centre, as well as the former federal capital of Nigeria, is the fastest growing urban area in Africa (Onwuanyi \& Oyetunji, 2015). Due to its prominence as the foremost property market in Nigeria, over $50 \%$ of Nigerian real estate professionals practice within the state (Olaleye, 2004; Babawale, 2008). Amidu, Aluko and Hansz (2008) report that more than half of the real estate consultancy firms in Nigeria locate their offices within the metropolis. The NIESV directory also suggests that $52 \%$ of the practitioners' firms are based in the Lagos metropolis (NIESV, 2002).

There are several CBD's in the Lagos metropolis due to the commercialintensive nature of the city. This gives opportunities for most real estate firms to concentrate along the $\mathrm{CBD}$ routes. The study location was stratified according to the locational pattern stratification method employed by Ogunba (2004). Lagos, which comprises the Island and Mainland divisions, consists of five major business districts (Ogunba, 2004). They include Marina and Ikoyi/Victoria Island for the Lagos Island CBDs, and Yaba/Ebute Meta, Apapa/Ijora and Ikeja for the Lagos Mainland CBDs. This method, therefore, assisted in pinpointing the most concentrated areas of real estate professionals in the various CBDs.

The population for the study is estate surveying and valuation firms with either head or branch office in Lagos. The rationale for the adoption of ESVs lies in the fact that they are the professionals created by law to carry out real estate duties, with stamp and seal, for execution of property valuation jobs. They are members of Estate Surveying and Valuation Registration Board of Nigeria (ESVARBON) who possess the required skills and undergo the necessary 
training that qualifies them to practice. The list of registered practising estate surveying and valuation firms in 2017 was obtained from the directory of NIESV. This list helped determine the sample frame of the population. Having stratified the study area into five zones namely: Marina, also known as Lagos Island, Victoria Island/Ikoyi, Apapa/Ijora, Yaba/Ebute Metta and Ikeja business districts. $50 \%$ of the estate firms were purposefully selected to represent the sample size of the respondents. Table 1 shows the sample of the target population.

Table 1: The Population Sample

\begin{tabular}{clcc}
\hline S/N & Stratum & Sample frame & Sample size \\
\hline 1 & Marina & 94 & 47 \\
2 & Ikoyi/Victoria Island & 52 & 26 \\
3 & Yaba/Ebute Meta & 38 & 19 \\
4 & Apapa/Ijora & 26 & 13 \\
5 & Ikeja & 134 & 67 \\
& & $\mathbf{3 4 4}$ & $\mathbf{1 7 2}$ \\
\hline
\end{tabular}

The questionnaire, as well as personal interviews, were used as instruments of data collection from the respondents. The questionnaire survey was employed to elicit information from the respondents due to the geographical settings of the study area. The questionnaire was structured with Likert responses. The data collected was then analysed using the factor analytical test. Factor analysis was carried out on the predictor variables to reduce them to a subset of uncorrelated factors. This technique is ideal for identifying clusters of related variables and helps reduce the variables into a more easily understood framework (Norusis, 2000). Tabachnick and Fidell (2007) suggest that the sample size of a study should be from 150 - 300 for factor analysis to be considered. However, Pallant (2005) states that there has been little agreement amongst authors concerning the size of a sample for factor analysis but recommend the use of a larger sample.

The sample size of 172 was used for this study is well within the range suggested by Tabachnick and Fidell. Regarding the number of variables, Hair et al. (1998) suggests that factor analysis is suitable for 20-50 variables, as the extraction of common factors becomes inaccurate if the number of variables exceeds this range. However, studies have shown that fewer variables can be used if the sample size can be significantly investigated (Ahadzie, Proverbs \& Olomolaiye, 2008). Hence the twenty variables used in this study can be considered adequate for the factor analysis.

To determine if the items in the questionnaire were internally consistent, a reliability test was run, and the result produced a Cronbach's alpha $(\alpha)$ value of 0.677. Oppenheim (1992) states that the degree of reliability of a research instrument is more perfect as they tend towards 1.00 . Therefore, the reliability 
test executed to investigate the factors necessitating the deployment of ICT in Nigeria's real estate practice shows that the variables in the questionnaires are consistent and the scales are internally reliable.

\section{Results and Discussion}

According to the literature, identified factors that necessitated the use of ICTs in Lagos' real estate practice were subjected to principal component analysis (PCA) with varimax rotation. Kaiser-Meyer-Olkin's (KMO) measure of sampling adequacy and Bartlett's Test of Sphericity were employed to test the factorability of the data gathered using the Statistical Package for Social Sciences (SPSS) version 23.0. KMO is a measure of homogeneity of variables used in testing whether the partial correlations among variables are small (Sharma, 1996). The KMO index ranges from 0 to 1 , with 0.6 suggested as the minimum value for a good factor analysis (Eiselen, Uys \& Potgieter, 2007; Tabachnick \& Fidell, 2007). Also, Bartlett's Test of Sphericity shows whether the correlation matrix is an identity matrix. According to George and Mallery (2003), a $\mathrm{p}<0.05$ indicates that the data does not produce an identity matrix and are thus acceptable for factor analysis. Pallant (2005) suggests that Bartlett's Test of Sphericity should be significant $(\mathrm{p}<0.05)$ for the factor analysis to be considered appropriate. The KMO obtained for this study is 0.722 at a significant level of 0.000 . This result coupled with the 0.677 obtained from the reliability test, shows that the use of factor analysis for the data gathered is appropriate. 
Table 2: Factors Influencing the Deployment of ICT in Nigerian Real Estate Practice

\begin{tabular}{|c|c|c|c|c|c|}
\hline \multirow{2}{*}{$\begin{array}{l}\text { Factors } \\
\text { Changing trends in technology }\end{array}$} & \multirow{2}{*}{$\begin{array}{l}\text { Commonalities } \\
.685\end{array}$} & \multirow[t]{2}{*}{ Factor groupings } & \multicolumn{3}{|c|}{ Cluster components matrix } \\
\hline & & & 0.811 & & \\
\hline The need to reduce personnel costs & .671 & & 0.580 & & \\
\hline Firm's affordability of computer software and hardware & .787 & & 0.849 & & \\
\hline To ease information transfer & .812 & Technology & 0.818 & & \\
\hline To eliminate distance barrier & .477 & Infrastructure & 0.674 & & \\
\hline To help in document and record keeping & .525 & & 0.787 & & \\
\hline To aid data presentation & .825 & & 0.772 & & \\
\hline To create more opportunities & .912 & & 0.849 & & \\
\hline The need to improve the firm quality of services & .754 & & & 0.807 & \\
\hline The need to increase the firm rate of turnover & .680 & & & 0.822 & \\
\hline To make complex task easier & .896 & Service Delivery & & 0.706 & \\
\hline Size of firm/organisation & .791 & Efficiency & & 0.867 & \\
\hline Enhance accuracy & .777 & Enhancement & & 0.868 & \\
\hline To enhance and speed up decision-making & .610 & & & 0.528 & \\
\hline To increase competition level among practitioners & .852 & & & & 0.862 \\
\hline The need to increase productivity & .687 & & & & 0.704 \\
\hline Attract more clients & .863 & Productivity & & & 0.896 \\
\hline Time-saving and management & .868 & Branding & & & 0.840 \\
\hline To portray the firm image & .770 & & & & 0.797 \\
\hline To make staff responsibilities easier & .796 & & & & 0.886 \\
\hline Eigen Values & & & 11.052 & 3.822 & 1.056 \\
\hline$\%$ of Variance & & & 48.707 & 7.497 & 5.366 \\
\hline
\end{tabular}

Source: Field Survey, 2017. 
Table 2 shows the factors influencing the use of ICTs, the commonalities, the component matrix, and the associated factor groupings. The Kaiser's criterion was used in retaining factors with Eigen values greater than 1.0. The factor analysis results in three factors with Eigen values exceeding 1.0. The first cluster of factors accounted for $48.707 \%$ of the total importance of factors that necessitated the use of ICTs in real estate practice. In the same vein, the second cluster factors accounted for $7.497 \%$, and the third cluster accounted for $5.366 \%$. These three clusters of factors together have a total cumulative percentage of $61.570 \%$ of the total importance and significance of the factors.

\section{Factor 1 - Technological Infrastructure Factors}

Eight items are included for Factor 1. All the items relate to the acquisition of technological factors needed to achieve success in the use of ICTs in real estate practice. These factors are:

- $\quad$ changing trends in technology

- $\quad$ the need to reduce personnel costs

- firm's affordability of computer software and hardware

- to ease information transfer

- to eliminate distance barrier

- $\quad$ to help in document and record keeping

- to create more opportunities' and 'to aid data presentation

Thus, they were labelled 'technological infrastructure factors' and had a total variance of $48.707 \%$.

The suitability of technology to every sector in an economy cannot be overemphasised. A good technological image is essential to improve the competitive edge of organisations in an increasingly complex and technologically conscious industry. Han and Lim (2001) confirm that some property management company's computer applications were lagging in the advancement of computer hardware and software. This could be a result of them dealing with a small portion of properties through the computer and the internet. Secondly, property management involves many personal touches, where the exclusive use of computers might not be helpful. Lastly, the available software packages cannot meet the requirement of some special property management tasks.

Due to an economic recession in Nigeria, some clients cannot afford to acquire properties nor pay for the services of real estate consultants because of the high costs involved. Hence, only wealthy members of society can engage the services of real estate consultants with good reputations. For this reason, some estate firms cannot afford to invest in ICTs, but would rather spend on essential office needs. This is corroborated by Kelly (1993) who suggests that the high cost of computers and software pose as a severe impediment to the accessibility of IT in Africa. Therefore, funding was a major obstacle to ICT investment, especially for small firms. Technology has gone beyond the use of traditional methods of keeping records such as 
cabinet filing systems, therefore, for organisations to remain in business and develop, they must keep in touch with emerging technological advancements within the profession.

\section{Factor 2 - Service Delivery Efficiency Enhancement Factors}

Factor 2 has six components. They include:

- $\quad$ the need to improve the firm quality of services

- the need to increase the firm rate of turnover

- to make complex tasks easier

- $\quad$ size of firm/organisation

- $\quad$ enhance accuracy

- $\quad$ to enhance and speed up decision-making

These factors were labelled 'service delivery efficiency enhancement factors' with a variance of $7.497 \%$.

Customers' satisfaction is the focus of every organisation since they are the reason for its existence. Many organisations have gone out of business as a result of not meeting the need of their customers. Kowtha and Choon (2001) believe that the adoption of such technology allows for firms to take a competitive advantage by reducing their costs and improving their reactivity to market changes and customer needs.

Due to the nature and complexity of the property market, there is a need for the presence of property experts who can assist clients in the market. Activities such as developing, buying, letting and disposing of property assets are some of the core business activities of real estate that require professional advice. Usually, property valuers are recognised as people who have the expertise in this area and can give advice to clients on a broad spectrum of property services (property valuation, real estate brokerage, conducting market studies and feasibility studies) (Ahmad Shazrinet, et al., 2014). The nature of these services often depends heavily on market knowledge to ensure that they can deliver the best services to the client. It is therefore likely that ICT will continue to create shifts and transformations in subtle ways. These developments will further change the needs and preferences of owners, occupiers and their customers (Dixon, 2005).

\section{Factor 3 - Productivity Branding Factors}

Six factors are included in Factor 3. They are:

- $\quad$ to increase competition level among practitioners

- the need to increase productivity

- $\quad$ attract more clients

- $\quad$ time-saving and management

- $\quad$ to portray the firm image

- $\quad$ to make staff responsibilities easier 
This factor was labelled, 'productivity branding factors'. It accounts for $5.366 \%$ of the variance.

Every product needs branding for it to be marketable. Most customers look out for the brand name before purchasing their goods. In real estate services, the goods traded therein involve the interest that subsist in the property. Therefore, most clients do not want to patronise non-professionals so as not to lose their investments. As a result, most firms need to be well-equipped to succeed in the competitive market by making their marketable products stand out. The success of an organisation in meeting its objectives depends on sound information management principles. Developments in technology have aided firms and organisations in sound management of their information for effective decision-making. ICTs have been shown to be a vital tool in assisting the real estate industry to cope with the increasing complexity of its products as well as the increasing demands of its clients and regulators (Liston, Fischer \& Kunz, 2000).

\section{Conclusion and Recommendations}

This research has examined the factors influencing the deployment of ICTs in contemporary real estate practice in Nigeria. Twenty factors were highlighted from the literature. These factors were assessed by respondents in relation to their influence on the use of ICT in Nigerian real estate practice and subsequent organisational efficiency. The factor analysis results clustered these variables into three factors, namely: technological infrastructure, service delivery efficiency enhancement, and productivity branding factors. The findings in this study agreed with that of Alam and Moh'd Kamal (2007) and Adeyemo et al. (2015). Both suggest that the increased productivity of staff, enhanced quality of customer services, knowledge sharing factor and information accessibility, improved decisionmaking, and time-saving are the most highly motivating factors influencing the use of ICTs in real estate practice. The findings are also in tandem with that of Hamdi (2013), who notes that technology will continue to improve various aspects of the construction industry including the services provided, the enhancement of efficiency, performance and consequently the productivity of the firms involved. Hence, the results also support the view of Peansupap and Walker (2005), who state that new technologies have resulted in cost reduction of communications through computerisation. The implication of the findings to the Nigerian real estate practice will appreciate the role of ICTs as a tool of enhancement for their mode of operation. Furthermore, it highlights the inherent benefits that arise with maximum utilisation of ICTs in this national sector. This will help in building Nigerian real estate databases and clients' satisfaction.

This study, therefore, recommends that the bodies shouldered with the responsibilities of regulating the profession should formulate necessary policies and guidelines that will ensure that practitioners and real estate firms benefit from ICT in real estate services. The government should also provide incentives to real estate firms to equip themselves with the latest technologies. This could be done with the help of NIESV by establishing 
special grants to ensure that the real estate industry positions itself to take up the challenge. Furthermore, there is a need for practitioners and real estate firms to follow recent trends and emerging concepts in technological advancement in their quest for survival, both in local and international markets.

\section{References}

Adeyemo, A. A., Kemiki, O. A., Adama, U. J. and Ayoola, A. B. (2015).

Factors Influencing the use of Information and Communication Technology in Real Estate Practice in Minna. ATBU Journal of Environmental Technology,8(2), pp.1-10.

Agarwal, R., and Karahanna, E. (2002). Time flies when you're having fun: Cognitive absorption and beliefs about information technology usage. MIS Quarterly, 24(4), pp.665-694.

Ahadzie, D. K., Proverbs, D. G and Olomolaiye, P.O. (2008). Critical success criteria for masshouse building projects in developing countries. International Journal of Project Management, 26(6), pp.675-687.

Ahmad Shazrin, M, A., Abdul Hadi, N., Siti Nur, F.A and Nur Lesya F. J. L. (2014). Knowledge management obstacles in real estate (valuation) organisations: Towards quality property services. AseanTurkey ASLI (Annual Serial Landmark International) conference on quality of life. ABRA international conference on quality of life, AQoL.

Alam, S. S. and Moh'd Kamal, M. (2007). ICT adoption in SMEs: An empirical evidence of service sectors in Malaysia. International Journal of Business and Management. 4(2).

Alam, S. S., Omar, N.A and NikHisham, N. (2011). Applying the theory of the perceived characteristics of innovating (PCI) on ICT adoption in SMEs in Malaysia. Australia Journal of Basic and Applied Sciences, 5(8), pp.8-17.

Amidu, R., Aluko B.T and Hansz, J.A.(2008). Client feedback pressure and the role of estate surveyors and valuers. Journal of Property Research, 25(2), pp.89-106.

Apulu, I. and Latham, A. (2011). Drivers for information and communication technology adoption: A case study of Nigerian small and medium sized enterprises. International Journal of Business and Management, 6(5), pp.51-60.

Arduin, D., Nascia, L., and Zanfei, A. (2010). Complementary approaches to the diffusion of ICT: Empirical evidence on Italian firms. Working paper, 2010-02 series in Economics, Mathematics and Statistics.

Asgarkhani, M., and Young, A. (2010). Industry view of ICT roles and skills in Canterbury. 1st Annual conference of computing and information technology research and education, New Zealand.

Ashaolu, T.A. (2011). Environmental benefits and challenges of ICT: The Lagos experience. International Journal of Applied Science and Technology,1(6), pp.184-188. 
Babawale, G. K. (2008). An evaluation of factors influencing inaccuracy in residential property valuation in Lagos metropolis, Nigeria. Unpublished $\mathrm{PhD}$ Thesis. Department of Estate Management, University of Lagos. Lagos, Nigeria.

Babawale, G. K. (2012). Paradigm shift in investment property valuation theory and practice: Nigerian practitioner's response. Mediterranean Journal of Social Sciences, 3(3), pp.217-228.

Bayo-Moriones, A and Lera-Lopez, F., (2007). A firm-level analysis of determinants of ICT adoption in Spain. Technovation, 27(6-7), pp.352-366.

BenYoussef, A., Hadhri, W and M'Henni, H. (2010). Intra-Firm diffusion of innovation: Evidence from Tunisian SME's in matters of information and communication technologies. Working paper 2010532.

Bocquet, R and Brossard, O., (2007). The variety of ICT adopters in the intra-firm diffusion process, theoretical arguments and empirical evidence. Structural Change and Economic Dynamics, 18(4), pp.409-437.

Bocquet, R., Brossard, O and Sabatier, M. (2007). Complementarities organisational design and the diffusion of information technologies. An empirical analysis. Research Policy, 36(3), pp.409-437.

Chang, K. (2004). Introduction to geographic information systems. $2^{\text {nd }}$ Edition. McGraw Hill, New York.

Cheong, D. (2006). What we do and can do for a living: Expanding the role of the real estate profession. Paper presented at world valuation congress XI, Kuala Lumpur, Malaysia. 1-14.

Chukwuemeka C. C. (2012). Application of technology in business:

Developing a web-based real-estate information system for the Nigerian market. A dissertation submitted to the University of Manchester.

Crowston, K; Sawyer, S and Wigand, R. (2001). Investigating the interplay between structure and technology in the real estate industry. Journal of Information Technology and People, 14(2), pp.163-183.

Cruzen, R. (2006). Internet interactions. http://www.car.org/index.php?id=MzY3Nji. Retrieved on 16th April, 2017.

Dixon, T. (2005). The impact of information and communications technology on commercial real estate in the new economy. Journal of Property Investment \& Finance, 23(6), pp.480-493.

Dixon, T. and Thompson, B. (2005). Connectivity, technological change and commercial property in the new economy: A new research agenda. College of Estate Management, Whiteknights, Reading, RG6 6AW, UK.

Egbu, C.O. and Botterill, K. (2002). Information technologies for knowledge management: Their use and effectiveness. Journal of Information Technology in Construction. Special Issue ICT for Knowledge Management in Construction, 7, pp.125-137.

Eiselen, R., Uys, T. and Potgieter, T. (2007). Analysing survey data using SPSS13. 3rd Edition. Johannesburg: Statkon, University of Johannesburg. 
Esben, A.S. (2012). Promoting the use of ICT in the construction industry: Assessing the factors hindering usage by building contractors in Ghana. A thesis submitted to the Department of Building Technology, Kwame Nkrumah University of Science and Technology-Kumasi, in partiafulfilmentnt of the requirements for the degree of Master of Science in Construction Management.

Gaith, F., Khalim, A. R. and Ismail, A. (2009). Usage of information technology in construction firms: Malaysian construction industry. European Journal of Scientific Research, 28(3), pp.412-421.

Gallego, J.M., Gutiérrez, L.H. and Lee, S.H. (2014). A firm-level analysis Of ICT adoption in an emerging economy: evidence from the Colombian manufacturing industries. Industrial and Corporate Change, 24(1), pp.191-221.

George, D. and Mallery, P. (2003). SPSS for windows step by step. A simple guide and reference. 11.0 Update. 4th Edition, Allyn \& Bacon, Boston.

Gitau, S.W. (2014). The application of information technology in real estate firms in Kenya. An unpublished research project submitted in partial fulfilment of the requirements for the award of the degree of Master in Valuation and Property Management, School of the Built Environment, University of Nairobi.

Gwin, C.R. (2004). International comparisons of real estate information on the internet. Journal of Real Estate Research, 26(1), pp.1-24.

Hair, J.F. Jr., Anderson, R.E., Tatham, R.L., and Black, W.C. (1998). Multivariate data analysis. (5th Edition). Upper Saddle River, NJ: Prentice Hall.

Hamdi, F. M. (2013). The impact of globalisation in the developing countries. Developing Country Studies, 3(11), pp.142-145.

Han, S, S, and Lim L, Y. (2001). Computers in property management companies. Journal of Property Management, 19(5), pp.433-440.

Hollenstein, H. (2004). Determinants of the adoption of information and communication technologies. An empirical analysis based on firmlevel data for the Swiss business sector. Structural Change and Economic Dynamic, 15(3), pp.315-342.

Jones, S and Benjamin, Z (2013). Framing ICT Usage in The Real Estate Industry. International Journal of Organisational Design and Engineering (IJODE), 3(2), pp.132.

Kakulu, I. I. (2003). Computerized approach to real estate practice in Nigeria. IBK Publication, Port Harcourt, Nigeria.

Kakulu, I. I. (2008). Capacity building for automated land information system in Nigeria. Paper presented at the strategic integration generation, FIG working week, Stockholm, Sweden.

Kasim, N.B and Ang, S. E. P (2010). The awareness of ICT Implementation for materials management in construction projects. International Journal of Computer and Communication Technology, 2(1), pp.110.

Kelly, M. (1993). A model of lawyers' text handling methods. International Journal of Law and Infraction Technology, 1 (3), p.354.

Kirkwood J. S. (2003). Urban Real Estate Information Systems: The 
Suppression of Radical Innovation. School of Environment and Development, Sheffield Hallam University, UK.

Kowtha, N. R and Choon, T. W. (2001). Determinants of website development: A study of electronic commerce in Singapore. Information and Management, 39(3), pp.227-242.

Kummerow, M.L. and Lun, J. (2005). Information and communication technology in the real estate industry: Productivity, industry structure and market efficiency. Telecommunications Policy, 29(2/3), pp.173-191.

Li, L.H., and Wang, C. (2006). Real estate agency in China in the information age. Property Management, 24(1), pp.47-61.

Liston K. M., Fischer M. A. and Kunz J. C. (2000). Designing and evaluation techniques for construction planning. Proceedings of the 8th International Conference on Computing in Civil and Building Engineering (ICCCBE-VIII), Stanford University, Stanford, CA, pp.293-300.

Markus, M., Dutta, A., Steinfield, C.W. and Wigand, R.T. (2008). The computerisation movement in the US home mortgage industry: Automated underwriting from 1980 to 2004', in Kraemer, K. and Elliott, M. (Eds.): Computerization movements and technology diffusion: From mainframes to ubiquitous computing. Information Today, pp.115-144

McAusland, C. (2010). Globalization's direct and indirect effects on the environment. Globalization, transport and the environment, ed. Nils A. Braathen (OECD), pp.31-54.

Muhanna, W. (2000). E-Commerce in the real estate brokerage industry. Journal of Real Estate Practice and Education, 3(1), pp.1-16.

Nielsen, Y., Hassan T.M and Çiftçi, Ç. (2007). Legal aspects of information and communication technologies implementation in the Turkish construction industry: Applicability of eLEGAL framework. Journal of Professional Issues in Engineering Education and Practice, 133(3), pp.255-264.

Norusis M.J. (2010). SPSS 10.0 Guide to data analysis. Englewood Cliffs, NJ: Prentice Hall.

Ogunba, O.A. (2004). Implementation hurdles in the search for rationality in investment valuation in Nigeria. Journal of Property Research and Construction, (1), pp.14-28.

Ogunsola, L. A. and Aboyade, W. A. (2005). Information and communications technology in Nigeria: Revolution or evolution. Journal of Social Science, 11(1), pp.7-14.

Oladapo, A.A (2006). The impact of ICT on professional practice in the Nigerian construction industry. The Electronic Journal on Information Systems in Developing Countries, 24(2), pp.1-19.

Olukolajo, M.A, Ojo, B. and Akinwamide, D.O. (2015). Assessment of use of social media in real estate transactions in Lagos property market. American Journal of Economics, Finance and Management, 1(2), pp.63-68.

Oppenheim, A. N. (1992). Questionnaire design, interviewing and attitude measurement. London: Pinter.

Onwuanyi, N. and Oyetunji, A.K. (2016). Revitalizing Nigeria's built 
heritage using facility management service delivery: The Lagos national arts theatre complex. International Journal of Sustainable Built Environment,5, pp.579-586.

Pallant, J. (2005). SPSS survival manual: A step by step guide to data analysis using SPSS for windows (version 12). 2nd Edition, Allen and Unwin, Crows Nest NSW 2065Australia.

Perkinson, C. L and Ahmad, I.U. (2006). Computing technology usage in construction contractor organizations. Fourth international Latin American and Caribbean Conference for Engineering and Technology (LACCET) Conference. Breaking frontiers and barriers in engineering: Education, research and practice. Mayagüez, Puerto Rico.

Peansupap V., and Walker D. (2005). Factors affecting ICT diffusion: A case study of three large Australian construction contractors. Engineering, Construction and Architectural Management, 12(1), pp.21-27.

Real Estate Insight (2010). Real estate developers - Finding ways out of the financial crisis through tax and innovation strategies. Alitheia Capital Limited, Lagos Nigeria. (Retrieved on November 28, 2016).

Reijo, S., Elias, J., Jouko, K., Miettinen, I. and Jussi, K. (2005). ICT as an enabler for conversion of real estate business to customer focused workplace industry. Helsinki, Sweden: Software Business and Engineering Institute (SoberIT). Helsinki University of Technology (HUT).

Reijo, S., Elias, J., Jouko, K., Miettinen, I. and Gersberg, N. (2007). ICT as an enabler for conversion of real estate business to customer focused workplace industry. Helsinki, Sweden: Software Business and Engineering Institute (SoberIT). Helsinki University of Technology (HUT).

Rowley, S. (2005). The evolution of internet business strategy: The case of UK estate agency. Property Management, 23(3), pp.217-226.

Sawyer, S. and Crowston, K. (1999). ICT in the real estate industry: Agents and social capital. Paper presented at AMCIS Proceedings.

Sawyer, S., Wigand, R. T., and Crowston, K. (2005). Redefining access: Uses and roles of information and communication technologies in the US residential real estate industry from 1995 to 2005. Journal of Information Technology, 20(4), pp.213-223.

Sawyer, S., Crowston, K., Wigand, R. and Allbritton, M., (2003). The social embeddedness of transactions: Evidence from the residential real estate industry. The Information Society, 19(2), pp.135-154.

Sharma, S. (1996). Applied multivariate techniques. Subhash Sharma. John Wiley and Sons, Inc., New York.

Sing, T. F., (2005). Impact of information and communications technology on real estate space: Perspective of office occupiers. Journal of Property Research, Investment and Finance, 23(6), pp.494-505.

Spanos, Y. E., Prastacos, G. P., and Poulymenakou, A. (2002). The relationship between information and communication technologies adoption and management. Information and Management, 39, pp.659-675.

Swanepool, S. and Tuccillo, J. (2003). Real estate confronts profitability. 
Real Estate White Paper. http://www.swanepool.com/publication/ Tabachnick, B.G. and Fidell, L.S. (2007). Using multivariate statistics 5th edition, Boston: Pearson Education.

Wigand, R. T., Crowston, K., Sawyer, S., and Allbritton, M. (2001).

Information and communication technologies in the real estate industry: Results of a pilot survey. Global co-operation in the new millennium. The 9th European Conference on Information Systems, Bled, Slovenia.

Yang, J., Ahuja, V., and Shankar, R. (2007). Managing building project through enhanced communication - An ICT based strategy for small and medium enterprises. CIB World Building Congress, 2007, CIB 2007-092, 2344-2357

Zumpano, L. V., Johnson, K. H. and Anderson, R. (2003). Internet use and real estate brokerage market intermediation. Journal of Housing Economics, 12(2), pp.134-150. 